\title{
PERAN DAN KINERJA PENYULUH PERTANIAN DALAM MEMBERDAYAKAN PETERNAK AYAM PETELUR DI KABUPATEN JEMBER
}

Oleh :

\author{
INDRI RAFIANI RAHMAWATI *), MUKSIN dan RIZAL **)
}

\begin{abstract}
ABSTRAK
Prospek usaha peternakan ayam ras petelur di Indonesia dinilai sangat baik dilihat dari pasar dalam negeri maupun luar negeri, jika ditinjau dari sisi penawaran dan permintaan. Di sisi penawaran, kapasitas produksi peternakan ayam ras petelur di Indonesia masih belum mencapai kapasitas produksi yang sesungguhnya. Salah satu upaya untuk meningkatkan kapasitas produksi peternakan ayam ras petelur diindonesia yaitu meningkatkan produksi peternakan ayam ras petelur yang ada dengan membuka usaha peternakan ayam petelur di empat Kecamatan Kabupaten Jember yaitu Kalisat, Jenggawah, Sumberbaru dan Mayang yang tidak mendirikan usaha peternakan ayam petelur dengan meningkatkan sumber daya manusia salah satu faktornya yaitu melalui peran, inovasi dan kinerja penyuluh dalam meningkatkan produksi dan keberdayaan peternak ayas petelur. Penelitian ini menggunakan metode sensus atau complete enumeration, dengan populasi sampel keseluruhan 57 peternak ayam ras petelur di 19 Kecamatan Kabupaten Jember. Analisis yang digunakan untuk menguji hipotesis dalam penelitian ini adalah SEM dengan Parsial Least Square (PLS). Hasil dari penelitian ini menunjukkan bahwa peran penyuluh, kinerja penyuluh dan inovasi penyuluh berpengaruh secara langsung dan signfikan terhadap keberdayaan peternak kemudian peran dan inovasi penyuluh berpengaruh secara langsung dan signifikan terhadap kinerja penyuluh.
\end{abstract}

Kata Kunci : Penyuluh Pertanian Kabupaten Jember, Peternak Ayam Petelur Kabupaten Jember, Peran, Kinerja, Inovasi, keberdayaan, SEM PLS.

\section{PENDAHULUAN}

Prospek usaha peternakan ayam ras petelur di Indonesia dinilai sangat baik dilihat dari pasar dalam negeri maupun luar negeri, jika ditinjau dari sisi penawaran dan permintaan. Di sisi penawaran, kapasitas produksi peternakan ayam ras petelur di Indonesia masih belum mencapai kapasitas produksi yang sesungguhnya (Abidin, 2003). Hal ini terlihat dari masih banyaknya perusahaan pembibitan, pakan ternak, dan obatobatan yang masih berproduksi sehingga prospek pengembangannya masih terbuka. Di sisi permintaan, saat ini produksi telur ayam ras baru mencukupi kebutuhan pasar dalam negeri sebesar $65 \%$. Sisanya dipenuhi dari telur ayam kampung, itik, dan puyuh. Pada tahun 2014, produksi telur dari ayam petelur di Kabupaten Jember sebesar $6.438 .329 \mathrm{~kg}$. Hal ini sangat besar potensi prospeknya untuk terus berkembang dimana sentra daerah pengembangan usaha peternakan ayam petelur di Kabupaten Jember terletak di daerah Balung, Sumber Jambe, Sukowono, Mumbulsari dan Sukorambi. (Sumber: Data Badan Pusat Statistik Jember 2014).
Tabel 1. Daerah sentra pengembangan usaha peternakan ayam petelur di Kabupaten Jember

\begin{tabular}{cll}
\hline No & Komoditas & $\begin{array}{l}\text { Daerah Sentra Ternak } \\
\text { Pada Kecamatan }\end{array}$ \\
\hline \multirow{2}{*}{$\begin{array}{l}\text { Ayam } \\
\text { Buras }\end{array}$} & $\begin{array}{l}\text { Sukowono, Umbulsari, } \\
\text { Gumukmas, Bangsalsari, } \\
\text { Silo }\end{array}$ \\
\hline \multirow{2}{*}{$\begin{array}{l}\text { Ayam } \\
\text { Potong }\end{array}$} & $\begin{array}{l}\text { Sukowono, Gumukmas, } \\
\text { Kencong, Rambipuji, } \\
\text { Pakusari }\end{array}$ \\
\hline \multirow{2}{*}{$\begin{array}{l}\text { Ayam } \\
\text { Petelur }\end{array}$} & $\begin{array}{l}\text { Balung, Sumberjambe, } \\
\text { Sukowono, Mumbulsari, } \\
\text { Sukorambi }\end{array}$ \\
\hline
\end{tabular}

Sumber: Data Badan Pusat Statistik Jember 2014.

Dari data BPS yang ada, terdapat permasalahan yang terjadi di lapangan mengenai peternakan ayam petelur di empat Kecamatan Kabupaten Jember yaitu Kalisat, Jenggawah, Sumberbaru dan Mayang yang tidak mendirikan usaha peternakan ayam petelur melainkan hanya melakukan usaha peternakan ayam buras dan ayam ras pedaging serta itik sehingga dapat berpengaruh terhadap permintaan pasar akan telur ayam di dalam negeri. Disisi lain didaerah tersebut mengalami keluhan kekurangan pegawai teknis penyuluh di lapangan yaitu di setiap kecamatan hanya ada 1 orang 
Indri Rafiani Rahmawati, Muksin dan Rizal, Peran dan Kinerja Penyuluh Pertanian Dalam Memberdayakan Peternak Ayam Petelur Di Kabupaten Jember

penyuluh teknis lapangan (PTL) sehingga program-program yang harus dijalan tidak terlaksana dengan baik, dimana setiap desa atau kecamatan membutuhkan peran, kinerja dan inovasi yang maksimal dari setiap penyuluh teknis dilapangan untuk pembuatan kelompok-kelompok tani, pembuatan proposal usulan usaha ayam petelur sampai dengan pelaksanaan dilapangan dan pendampingan secara kontinyu/berkelanjutan. Faktor lain yang mempengaruhi tidak berdirinya peternakan ayam petelur salah satunya di Kecamatan Mayang disebabkan kurangnya sosialisasi mengenai peternakan ayam petelur oleh petugas penyuluh lapangan sehingga minat yang terjadi di kecamatan tersebut lebih cenderung memilih usaha peternakan itik karena menurut para petani lebih menghasilkan baik dari segi harga telur yang lebih mahal dan cara pemeliharaannya yang tidak terlalu rumit. Dengan demikian untuk mengembangkan usaha peternakan ayam ras petelur di Kabupaten Jember diperlukan adanya peran, kinerja dan inovasi penyuluh pertanian dalam memberdayaan peternak ayam ras petelur, dan keikutsertaan pemerintah dalam menunjang usaha peternakan ayam ras petelur untuk dapat meningkatkan perekonomian dalam negeri. Selain itu diharapkan aparatur desa atau kecamatan dapat mendukung serta membantu menangani permasalahan tersebut agar dapat menciptakan peluang untuk dapat mendirikan usaha peternakan ayam petelur di empat kecamatan tersebut.

Penyuluh pertanian memegang peranan penting dalam meningkatkan kualitas sumberdaya petani/peternak. Melalui proses pembelajaran, peternak diharapkan mampu mengakses informasi teknologi, permodalan, pasar dan informasi lain sesuai kebutuhan sehingga dapat meningkatkan produktivitas, efisiensi usaha, pendapatan dan diupayakan tidak menimbulkan ketergantungan peternak kepada penyuluh agar peternak dapat lebih mandiri dengan memposisikannya sebagai wiraswasta agribisnis. Hal ini membutuhkan kinerja penyuluh pertanian yang terintegrasi pada pelaksanaan tugas pokok dan fungsi penyuluh pertanian dalam merencanakan, mengorganisasikan, dan mengevaluasi program penyuluh pertanian (Muhammad Ikbal Bahua,dkk, 2010).

Beberapa hasil kajian empiris penelitian terdahulu yang dilakukan oleh Roza Yulida, dkk (2012). Menunjukkan peran penyuluh berpengaruh secara signifikan terhadap perubahan perilaku petani. Syahputra, A. W dan Hariadi, S. S (2012) Peran penyuluh dan kearifan local berpengaruh signifikan terhadap adopsi inovasi padi sawah di Kecamatan Montasik Kabupaten Aceh Besar. Kemudian Menurut Sulistyati, dkk (2011). Proses pemberdayaan berpengaruh nyata terhadap keberdayaan peternak domba.

\section{Tujuan Penelitian}

1. Untuk menganalisis pengaruh peran penyuluh terhadap keberdayaaan peternak ayam petelur di Kabupaten Jember.

2. Untuk menganalisis pengaruh kinerja penyuluh terhadap keberdayaan peternak ayam petelur di Kabupaten Jember.

3. Untuk menganalisis pengaruh inovasi penyuluh terhadap keberdayaan peternak ayam petelur di Kabupaten Jember.

4. Untuk menganalisis pengaruh peran penyuluh terhadap kinerja penyuluh ayam petelur di Kabupaten Jember.

5. Untuk menganalisis pengaruh inovasi penyuluh terhadap kinerja penyuluh ayam petelur di Kabupaten Jember.

\section{METODE PENELITIAN \\ Rancangan Penelitian}

Rancangan penelitian adalah suatu usulan untuk memecahkan masalah dan merupakan rencana kegiatan yang dibuat oleh peneliti untuk memecahkan masalah, sehingga akan diperoleh data yang valid sesuai dengan tujuan penelitian (Arikunto, 2006). Penelitian ini merupakan penelitian penjelasan (explanatory research), yaitu penelitian yang mencoba untuk menjelaskan suatu pokok permasalahan dan terdapat sebuah pengujian hipotesa serta melakukan analisis dari data yang diperoleh (Murti dan Salamah, 2006).

\section{Waktu dan Lokasi Penelitian}

Penelitian dilaksanakan di Dinas Peternakan dan Perikanan Kabupaten Jember, Badan Pusat Statistik serta 19 Kecamatan di Kabupaten Jember selama 3 bulan dari bulan Juli sampai dengan September 2015. Pertimbangan pemilihan lokasi kajian ini adalah keseluruhan jumlah penyuluh Peternakan dan Perikanan di Kabupaten Jember dan seluruh peternak ayam ras petelur di 19 Kecamatan Kabupaten Jember.

\section{Populasi dan Sampel}

Menurut Arikunto (2006) populasi adalah keseluruhan subjek penelitian. Sugiyono (2009). Populasi penelitian ini adalah keseluruhan penyuluh Peternakan dan Perikanan di Kabupaten Jember yang berjumlah 31 orang dan 57 peternak ayam ras petelur di 19 Kecamatan Kabupaten Jember. Penelitian ini menggunakan metode sensus atau complete enumeration, yaitu penelitian 
dilakukan terhadap seluruh penyuluh di Kabupaten Jember dan seluruh peternak ayam ras petelur pada 19 Kecamatan di Kabupaten Jember Provinsi Jawa Timur, atau dengan kata lain penelitian ini tidak menggunakan sampel sehingga teknik pengambilan sampel juga tidak diperlukan. Dengan demikian, mengacu pada pendapat Cooper and Emory (1995:214), Indriantoro dan Supomo (2002:115), dan Suparmoko (1996:20), jika seluruh peternak ayam ras petelur di 19 Kecamatan Kabupaten Jember Provinsi Jawa Timur tersebut didefinisikan sebagai populasi, maka setiap sensus akan mendapatkan informasi atau data dari setiap peternak tersebut.

\section{Metode Analisis Model Persamaan Struktural}

Evaluasi dalam model PLS terdapat dua tahap yaitu :

a. Evaluasi terhadap model pengukuran (Outer Model)

Penilaian validitas model pengukuran dengan indicator reflektif dievaluasi dengan convergent validity dan discriminant validity dari indikatornya serta composite reability untuk variabel indikatornya. Convergen validity dari model pengukuran dengan indicator refleksif dilihat dari rata-rata varians diekstraksi (AVE). Convergent validity dikatakan cukup apabila nila AVE lebih besar sama dengan dari 0,5. Hal tersebut menunjukkan bahwa variable laten menjelaskan lebih dari setengah varians indikatornya (Hair et al, 2011).

Untuk penilaian discriminant validity seperti yang diungkapkan oleh Jaya dan Sumertajaya (2008) bahwa Membandingkan nilai square root of average variance extracted (AVE) setiap konstruk dengan korelasi antar konstruk lainnya dalam model, jika square root of average varianst extracted (AVE) konstruk lebih besar dari korelasi dengan seluruh konstruk lainnya maka dikatakan memiliki discriminate validity yang baik. Direkomendasikan nilai pengukuran harus lebih besar dari 0,50.

$\mathrm{AVE}=\frac{\Sigma_{i}^{k} \lambda_{i}^{2}}{\Sigma_{i}^{k} \Sigma_{i}^{k}+\Sigma_{i}^{k}\left(1-\lambda_{i}^{2}\right)}$

Berikut adalah rumus AVE:

Keterangan :

AVE : pengukuran reliabilitas komponen skor variabel laten

$\lambda i \quad$ : komponen faktor loading ke-I dengan $\mathrm{i}=$ $1,2, \ldots k$ (banyaknya indikator)
Composite reliability merupakan kelompok indikator yang mengukur sebuah variabel memiliki reliabitas komposit yang baik

jika memiliki composite reliability lebih besar atau sama dengan 0,70, walaupun bukan merupakan standar yang absolut. Composite reliability dapat dihitung dengan rumus

$$
\rho_{c}=\frac{\left(\sum_{i}^{k} \lambda_{i}\right)^{2}}{\left(\sum_{i}^{k} \lambda_{i}\right)^{2}+\sum_{i}^{k}\left(1-\lambda_{i}^{2}\right)}
$$

sebagai berikut :

dimana $\lambda_{i}$ merupakan komponen faktor loading keI dengan $\mathrm{i}=1,2, \ldots k$ (banyaknya indikator).

b. Evaluasi terhadap model struktural (Inner Model)Menurut Hair et al (2011), evaluasi terhadap model struktural dapat dilakukan dengan melihat besarnya $\mathrm{R}^{2}$ (R-square) untuk variabel dependent dengan menggunakan ukuran Q2 dan besar koefisien jalur struktural. Untuk mendapatkan koefisien signifikansi harus mengestimasi dengan bootstrapping dengan menggunakan uji t-statistik.

Persamaan yang dihasilkan pada penelitian ini adalah persamaan model struktural, karena tujuan penelitian ini adalah ingin mengetahui pengaruh antar variabel yang diteliti. Persamaan struktural diajukan dalam model konseptual penelitian seperti pada Gambar 1 berikut ini:

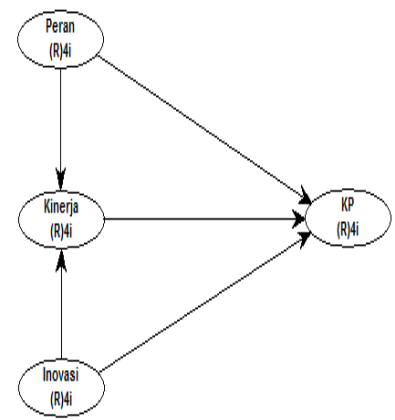

Gambar 1. Formulasi Model SEM PLS

Keterangan gambar:

a. Peran penyuluh pertanian sebagai variabel bebas (independent variable) pertama (X1), dengan indikator sebagai berikut:

1. Peran sebagai Fasilitator (Facilitative Roles) (X1)

2. Peran sebagai Pendidik (Educational Roles) (X2)

3. Peran sebagai Utusan atau Wakil (Representasional Roles) (X3) 
Indri Rafiani Rahmawati, Muksin dan Rizal, Peran dan Kinerja Penyuluh Pertanian Dalam Memberdayakan Peternak Ayam Petelur Di Kabupaten Jember

4. Peran sebagai Teknikal (Technical Roles) (X4)

b. Kinerja penyuluh pertanian sebagai variabel bebas (independent variable) kedua, (X2) dengan indikator sebagai berikut:

1. Pengetahuan, kemampuan, dan keterampilan dalam pekerjaan (X5)

2. Sikap kerja (X6)

3. Mutu pekerjaan (X7)

4. Interaksi (X8)

c. Inovasi penyuluh pertanian sebagai variabel bebas (independent variable) ketiga, (X3) dengan indikator sebagai berikut:

1. Inovasi yang dibutuhkan dalam mengatasi masalah (X9)

2. Inovasi untuk memberikan keuntungan kepada peternak (X10)

3. Memiliki kompatibilitas atau keselarasan (X11)

4. Inovasi yang mudah untuk diamati (X12)

d. Keberdayaan peternak ayam ras petelur sebagai variabel terikat (dependent variable)

(Y1) dengan indikator sebagai berikut:

1. Tingkat kesadaran dan keinginan untuk berubah (power to) (Y13)

2. Tingkat kemampuan meningkatkan kapasitas untuk memperoleh akses (power within) (Y14)

3. Tingkat kemampuan menghadapi hambatan (power over) (Y15)

4. Tingkat kemampuan kerjasama dan solidaritas (power with) (Y16)

\section{HASIL DAN PEMBAHASAN}

\section{Uji Validitas}

Uji validitas konstruk dilakukan bertujuan untuk melihat indikator yang layak untuk mewakili konstruk pada penelitian ini. Pengujian dilakukan dengan menggunakan confirmatory factor analysis (CFA) pada masing-masing variabel laten dengan

Tabel. 2 Loading Factor
\begin{tabular}{|c|r|c|}
\hline Indikator & Loading Factor & Validitas \\
\hline P1 & 0.828 & Valid \\
\hline P2 & 0.662 & Valid \\
\hline P3 & 0.639 & Valid \\
\hline P4 & 0.713 & Valid \\
\hline K1 & 0.662 & Valid \\
\hline K2 & 0.853 & Valid \\
\hline K3 & 0.734 & Valid \\
\hline K4 & 0.754 & Valid \\
\hline I1 & 0.639 & Valid \\
\hline I2 & 0.734 & Valid \\
\hline I3 & 0.800 & Valid \\
\hline I4 & 0.737 & Valid \\
\hline KP1 & 0.713 & Valid \\
\hline KP2 & 0.754 & Valid \\
\hline KP3 & 0.737 & Valid \\
\hline KP4 & 0.832 & Valid \\
\hline Sumber : Data diolah 2015 & \\
\hline
\end{tabular}

Nilai loading factor $(\lambda) \geq 0.50$ dan memenuhikriteria goodness of fit.

\section{Uji Reliabilitas Konstruk}

Uji reliabilitas yang digunakan adalah uji reliability analysis model Alpha Cronbach. Apabila koefisien reliabilitas lebih dari 0,7 maka instrumen dinyatakan reliabel pada taraf kepercayaan $95 \%$. Nilai reliabilitas masing-masing variabel $\geq 0.70$ sehingga semua variabel reliable atau konsisten. (Peran:0.897, Kinerja:0.914, Inovasi:0.876 dan Keberdayaan:0.900).

\section{Analisis SEM-PLS}

Hasil analisis hipotesis dan estimasi model dapat dijelaskan pada Gambar 2. berikut ini:

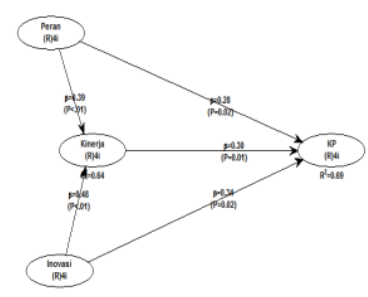

Gambar 2. Hasil Pengujian Hipotesis SEM-PLS

Pada bagian berikut diuraikan hasil pengujian hipotesis dengan menggunakan model struktural SEM-PLS. Hasil pengujian hipotesis ditunjukkan dalam gambar 2. Output pengujian dengan program WarpPLS 3.0 pada gambar 2 . Menunjukkan bahwa pengaruh Peran Penyuluh adalah signifikan terhadap keberdayaan peternak dengan nilai p sebesar 0.02 (di bawah 0.05). Kinerja Penyuluh berpengaruh signifikan 
terhadap keberdayaan peternak dengan nilai $p$ sebesar 0.01 (di bawah 0.05). Inovasi Penyuluh berpengaruh signifikan terhadap keberdayaan peternak dengan nilai $\mathrm{p}$ sebesar 0.01 (di bawah 0.05). Peran Penyuluh berpengaruh signifikan

\begin{tabular}{cccc}
\hline Total effect & Peran & Kinerja & Inovasi \\
\hline Kinerja & 0.387 & - & 0.475 \\
\hline Keberdayaan & 0.393 & 0.299 & 0.482 \\
\hline
\end{tabular}

terhadap kinerja penyuluh dengan nilai $\mathrm{p}<0.01$ (di bawah 0.05) dan Inovasi Penyuluh berpengaruh signifikan terhadap Kinerja Penyuluh dengan nilai p sebesar 0.01 (di bawah 0.05).

\section{Analisis Koefisien Determinasi ( $\left.\mathbf{R}^{\mathbf{2}}\right)$}

Berdasarkan Gambar 2 substruktural 1 diperoleh nilai koefisien determinasi totalnya $\left(\mathrm{R}^{2}\right)$ sebesar 0.64 dengan demikian maka besarnya konstribusi untuk peran penyuluh dan inovasi penyuluh secara bersama- sama terhadap variabel Kinerja Penyuluh adalah sebesar 64\%. Sementara sisanya sebesar $36 \%$ dipengaruhi oleh variabel lain selain peran penyuluh dan inovasi penyuluh yang tidak diikutkan dalam penelitian ini.

Berdasarkan Gambar 2 substruktural 2 diperoleh nilai koefisien determinasi totalnya $\left(\mathrm{R}^{2}\right)$ sebesar 0.69 dengan demikian maka besarnya konstribusi untuk peran penyuluh, inovasi penyuluh dan kinerja penyuluh secara bersama-sama terhadap variabel Keberdayaan Peternak adalah sebesar $69 \%$. Sementara sisanya sebesar $31 \%$ dipengaruhi oleh variabel lain selain peran penyuluh, inovasi penyuluh dan kinerja penyuluh yang tidak diikutkan dalam penelitian ini.

\section{Pengaruh Antar Variabel}

a) Pengaruh tidak langsung

Berdasarkan Tabel 3. variabel inovasi menunjukkan pengaruh secara tidak langsung yang paling dominan terhadap terhadap variabel keberdayaan yaitu nilai koefisien jalur pengaruh tidak langsung sebesar 0.142, maka selain variabel peran dan kinerja secara tidak langsung variabel inovasi yang menentukan keberdayaan peternak.

\begin{tabular}{l|l|l|l}
\multicolumn{4}{c}{ Tabel 3.Pengaruh tidak langsung } \\
\hline $\begin{array}{c}\text { Indirrect } \\
\text { effect }\end{array}$ & Peran & Kinerja & Inovasi \\
\hline Peran & - & - & - \\
\hline Keberdayaan & 0.116 & - & 0.1 \\
4
\end{tabular}

b) Pengaruh total

Berdasarkan Tabel 4. dapat dijelaskan bahwa pengaruh total paling dominan dari variabel laten eksogen terhadap variabel laten endogen adalah variabel inovasi terhadap keberdayaan dengan nilai koefisien jalur sebesar 0.482, menunjukkan bahwa inovasi memiliki peranan sangat penting terhadap keberdayaan peternak. Sedangkan pengaruh total terkecil adalah variabel kinerja terhadap keberdayaan dengan nilai koefisien jalur sebesar 0.299.

Hasil analisis penelitian ini menunjukkan bahwa pengaruh peran, kinerja dan inovasi terhadap keberdayaan, serta pengaruh peran dan inovasi terhadap kinerja menunjukkan hasil yang berbeda.

\section{KESIMPULAN}

1. Hipotesis pertama yang secara teoretik menduga bahwa peran penyuluh berpengaruh terhadap keberdayaan peternak secara empirik terbukti signifikan, sehingga $\mathrm{H} 1$ diterima. Jadi semakin baik peran penyuluh akan berpengaruh terhadap keberdayaan peternak di Kabupaten Jember.

2. Hipotesis kedua yang secara teoretik menduga bahwa kinerja penyuluh berpengaruh terhadap keberdayaan peternak secara empirik terbukti signifikan, sehingga $\mathrm{H} 2$ diterima. Jadi semakin baik kinerja penyuluh akan berpengaruh terhadap keberdayaan peternak di Kabupaten Jember.

3. Hipotesis ketiga yang secara teoretik menduga bahwa inovasi penyuluh berpengaruh terhadap keberdayaan peternak secara empirik terbukti signifikan, sehingga $\mathrm{H} 3$ diterima. Jadi semakin tinggi inovasi penyuluh akan berpengaruh terhadap keberdayaan peternak di Kabupaten Jember.

4. Hipotesis keempat yang secara teoretik menduga bahwa peran penyuluh berpengaruh terhadap kinerja peternak secara empirik terbukti signifikan, sehingga $\mathrm{H} 4$ diterima. Jadi semakin baik peran penyuluh akan berpengaruh terhadap kinerja penyuluh di Kabupaten Jember.

5. Hipotesis kelima yang secara teoretik menduga bahwa inovasi penyuluh berpengaruh terhadap kinerja peternak secara empirik terbukti signifikan, sehingga H5 diterima. Jadi semakin tinggi inovasi penyuluh akan berpengaruh terhadap kinerja penyuluh di Kabupaten Jember.

\section{DAFTAR PUSTAKA}

Abidin, Z., 2003. Meningkatkan Produktivitas Ayam dan Itik Ras Petelur. Cetakan Pertama. PT Agromedia Pustaka. Jakarta. 1, $7,23$.

Amstrong, Jim and Robin Ford., 2002. Public Sector Innovation and Public Interest 
Indri Rafiani Rahmawati, Muksin dan Rizal, Peran dan Kinerja Penyuluh Pertanian Dalam Memberdayakan Peternak Ayam Petelur Di Kabupaten Jember

issues, http://www.innovation.cc/discussion paper/ Pub Sector Innovation and Public Interest, htm, March 13, 2004, p. 1. (Download 9 September 2014).

Ani. L, dan Jahi. A., 2006. Kinerja Penyuluh Pertanian di Beberapa Kabupaten Provinsi Jawa Barat. Jurnal Penyuluhan Vol. 2 No. 2. ISSN: 1858-2664. Institut Pertanian Bogor.

Arikunto, S. 2006. Prosedur Penelitian, Suatu Pendekatan Praktek, Rineka Cipta, Jakarta.

Badan Litbang Pertanian. 2006. Pemupukan Fosfat dan Kalium Tanah Sawah, di Kab. Pemalang. Badan Penelitian dan Pengembangan Pertanian. Jakarta.

Bahua, M.I., A. Jahi, P.S. Asngari, A. Saleh dan I.G.P Purnaba. 2010. Faktor-Faktor yang Mempengaruhi Kinerja Penyuluh Pertanian dan Dampaknya pada Prilaku Petani Jagung Di Provinsi Gorontalo. Jurnal Ilmiah Agropolitan. Vol 3, No. 1, April 2010; 293 -303.

Bandura, Albert., 1986. Social foundations thought and action a social cognitive and theory practice. Hall inc. New Jersey.

Bekti et al., 2008. Kinerja Penyuluh Pertanian Lapang (PPL) Dalam Pengembangan Beras Organik Menuju Terwujudnya Kabupaten Sragen Sebagai Sentra Beras Organik. Agritexts No. 24. Semarang.

Browne M.W. dan R. Cudeck (1993),”Testing Structural Equation Model, Sage, Publication.

Byrne, B.M. (1998). SEM With LISREL, PRELIS, SIMPLIS : Basic Consepts, Application, and Programming. New Jersey : Lawrence Erlbaum Associates (LEA).

Departemen Pertanian. 2002. Gerakan Industrialisasi Pertanian di Pedesaan “(GERINDA 2020)". Direktorat Jenderal Bina Pengolahan dan Pemasaran Hasil Pertanian, Departemen Pertanian. Jakarta.

Diamantopoulos. A, J. Siguaw., 2000. Introducing LISREL. SAGE, London.

Dina Lesmana., 2007. Kinerja Balai Penyuluhan Pertanian Kota Samarinda. EPP Vol. 4
No. 2:24-31. Universitas Mulawarman. Samarinda.

Dyne, V. L, and Graham, J.W., 2005. "Organizational Citizenship Behavior; Construct Redefinition Measurement and Validation”. Academy Management Journal. 37, (4),765-802.

Ekaningtyas Kushartanti., 2001. Keefektifan Media Cetak Pada Diseminasi dan Adopsi Teknologi Jagung Bisma di Kabupaten Semarang. Thesis Program Pasca Sarjana UGM Yogyakarta.

Fawziah S., S.Bachrein., 2005. Penyelenggaraan fungsi informasi dan Komunikasi serta diseminasi hasil pengkajian BPTP. Pross. Lokakarya Pertemuan Regional BPTP.

Ferdinand, A.T., 1999. Strategic Pathways Toward Sustainable Competitive Advantage. Unpublished DBA Thesis, Southern Cross, Lismore, Australia, pp. 52.

Firmansyah, H., 2012. Ketercapaian Indikator Keberdayaan Masyarakat dalam Program Pemberdayaan Fakir Miskin (P2FM) di Kota Banjarmasin. Jurnal Agribisnis Pedesaan Vol. 2 Nomor 02

Ghozali, Imam., 2005. Aplikasi Analisis Multivariate dengan SPSS. Semarang: Universitas Diponegoro.

Ghozali, Imam., 2011. Aplikasi Analisis Multivariate Dengan Program IBM SPSS 19 (edisi kelima). Semarang: Universitas Diponegoro.

Hair, Joseph F. et al., 1998. Multivariate Data Analysis. New Jersey: Prentice-Hall, Inc.

Haryono, Siswoyo dan Wardoyo, Parwoto. 2013. Structural Equation Modelling untuk Penelitian Manajemen menggunakan Amos 18. Jawa Barat : PT. Intermedia Personalia Utama.

Hurley, Robert F. and G. Thomas M. Hult., 1998. Innovation, Market Orientation, and Organizational Learning: an Integration and Empirical Examination, Journal of Marketing, Vol. 62, (July 1998), pp. 42-54.

Ilham, T. 2010. Diversifikasi Pangan dan Penyuluhan Pertanian Sebagai Upaya Mewujudkan Ketahanan Nasional. Kompas. Diakses 8 Januari 2010. 
Indriantoro, dan Supomo, 2002. Metodologi Penelitian Bisnis untuk Akuntansi dan Manajemen. Edisi Pertama. Yogyakart: BPFE.

Istiningsih., 2008. Kinerja Penyuluh Pertanian Kabupaten Kulon Progo, Gunungkidul, Sleman dan Bantul di Era Otonomi Daerah. Jurnal Ilmu-ilmu Pertanian Vol. 4 No. 1. ISSN: 1858-1226. Yogyakarta.

Kartasapoetra, A.G. 1994. Teknologi Penyuluhan Pertanian. Jakarta: Bumi Aksara.

Keban, Yeremias. T. 2004. Enam Dimensi Strategis Administrasi Publik, Konsep, Teori, dan Isu. Yogyakarta. Gava Media.

Klausmeier, HJ. \& Goodwin, W., 1975. Learning and Human Abilities: Educational

Psychology. New York: Holt, Rinehart and Winston.

Kusmiyati, Maryani dan Kusnadi. 2010. Kinerja Penyuluh Pertaian PNS Dalam Melaksanakan Tupoksi Di Kabupaten Bogor. Jurnal Penyuluhan. Vol. 5. No 1: 87103.

Latan, Hengky, 2012, Structural Equation Modeling, Konsep dan Aplikasi Menggunakan Program Lisrel 8.80. Penerbit Alfabeta. Bandung.

Leonard-Barton., 1995. Well Spring of Knowledge. Hardvard Business School Press, NJ USA.

Malian, A. H. 2004. Kebijakan Perdagangan Internasional Komoditas Pertanian Indonesia. Jurnal Analisis Kebijakan Pertanian. Vol 2, 135-156

Mardikanto, T. 1993. Penyuluhan Pembangunan Pertanian. Surakarta: Sebelas Maret University Press.

Mardikanto, Totok. 1994. Dasar-dasar Teori Penyuluhan Pertanian. UNS Press. Surakarta.

Marliati et al., 2008. Faktor-Faktor Penentu Peningkatan Kinerja Penyuluh Pertanian Dalam Memberdayakan Petani. Jurnal Penyuluhan Vol. 4 No. 2. ISSN: 1858-2664. Institut Pertanian Bogor.
Mosher, A.T. 1997. Menggerakkan dan Membangun Pertanian. Jakarta: Yasa Guna.

McKenna. E and Beech. N., 2000. Manajemen Sumber Daya Manusia. Edisi terjemahan. Andi, Yogyakarta.

Musyafak Ahmad dan Tatang M.Ibrahim., 2005. Strategi Percepatan Adopsi dan Difusi Teknologi Pertanian dalam Prima Tani. Jurnal Analisis Kebijakan Pertanian, Vol.1.No.1, Maret 2005.

Nova et al., 2011. Kajian Kinerja Penyuluh Pertanian Di Wilayah Kerja Balai Penyuluh Pertanian, Perikanan dan Kehutanan (BP3K) Kecamatan Amurang Timur. Jurnal Penelitian.

Padmowihardjo, S. 2004. Menata Kembali Penyuluhan Pertanian di Era Pembangunan Agribisnis. Jakarta: Departemen Pertanian.

Prawirosentono, Suryadi., 1999. Kebijakan Kinerja Karyawan. Yogyakarta: BPFE.

Puji H, Surung. M. Y, dan Wahab. A., 2011. Analisis Kinerja Penyuluh Pertanian di Kabupaten Bantaeng Sulawesi Selatan. Jurnal Agrisistem Vol. 7 No. 2. ISSN: 20890036. Gowa.

Rasyid, M.A., 2001. Sangat Diperlukan Kegiatan Penyuluhan Pertanian. Ekstensia. Vol 13 tahun VII. September 2001.

Rennekamp, R.A., 2001. An Examinition of Customer Satisfaction in the Kentucky Cooperative Extension Service. Journal of Extension Volume 39 No. 2.

Risna, Rosni. M, dan Mariani., 2012. Peran Penyuluhan Pertanian Terhadap Pengendalian Hama Terpadu pada Tanaman Padi Berdasarkan Kelas 1 Kemampuan Kelompok Tani di Kecamatan Labuan Amas Selatan Kabupaten Hulu Sungai Tengah. Jurnal Agribisnis Pedesaan. Vol. 2 No. 3.

Roza. Y, Kausar, dan Marjelita L., 2012. Dampak Kegiatan Penyuluhan Terhadap Perubahan Perilaku Petani Sayuran di Kota Pekanbaru. Indonesian Journal of Agricultural Economics (IJAE) Vol. 3 No. 1. ISSN: 2087-409X. Pekanbaru. 
Indri Rafiani Rahmawati, Muksin dan Rizal, Peran dan Kinerja Penyuluh Pertanian Dalam Memberdayakan Peternak Ayam Petelur Di Kabupaten Jember

Saadah, Sulili. A, Deserama. dan R. D., 2011. Peranan Penyuluhan Pertanian Terhadap Pendapatan Petani yang Menerapkan Sistem Tanam Jajar Legowo. Jurnal Agrisistem, Vol. 7 No. 2. ISSN: 2089-0036.

Sapar et al., 2011. Faktor-Faktor yang Berpengaruh Pada Kinerja Penyuluh Pertanian dan Dampaknya Pada Kompetensi Petani Kakao di Empat Wilayah Sulawesi Selatan.

Setiana. L. 2005. Teknik Penyuluhan Dan Pemberdayaan Masyarakat. Bogor: Ghalia Indonesia.

Sugiono. 2006. Metode Penelitian Kuantitatif, Kualitatif dan R\&D. Bandung: Alfabeta.

Sugiyono, 2008. Metode Penelitian Bisnis. Cetakan kedua belas, CV Alfabeta, Bandung.

\begin{tabular}{|c|c|c|}
\hline $\begin{array}{c}\text { Sumardjo., } 1999 . \\
\text { Penyuluhan } \\
\text { Pengembangan }\end{array}$ & $\begin{array}{l}\text { "Transformasi } \\
\text { Pertanian } \\
\text { Kemandirian }\end{array}$ & $\begin{array}{r}\text { Model } \\
\text { Menuju } \\
\text { Petani: }\end{array}$ \\
\hline Kasus di Propins & si Jawa Barat". & Dis \\
\hline $\begin{array}{l}\text { Doktor. Bogor: } \\
\text { Institut Pertanian }\end{array}$ & $\begin{array}{l}\text { Program } \\
\text { ogor. }\end{array}$ & cas \\
\hline
\end{tabular}

Sumarni, Murti dan Salamah Wahyuni, 2006. Metodologi Penelitian Bisnis, CV Andi Offset, Yogyakarta.

Syahputra, A. W dan Hariadi, S. S., 2012. Pengaruh Peran Penyuluh dan Kearifan Lokal Terhadap Adopsi Inovasi Padi Sawah di Kecamatan Montasik Kabupaten Aceh Besar. KANAL, Vol. 1 Hal. 1-101. Yogyakarta.

Van den Ban, A.W dan H. S. Hawkins., 1999. Penyuluhan Pertanian. Yogyakarta: Kanisius.

Wibowo., 2007. Manajemen Kinerja. Jakarta: PT. Rajagrafindo Persada. 